UDC $575.1+577.11+577.21$

\title{
Novel gene PUS3 c.A212G mutation in Ukrainian family with intellectual disability
}

\author{
R. V. Gulkovskyi ${ }^{1,2}$, S. Y. Chernushyn ${ }^{1}$, L. A. Livshits ${ }^{1,2}$ \\ ${ }^{1}$ Institute of Molecular Biology and Genetics, NAS of Ukraine \\ 150, Akademika Zabolotnoho Str., Kyiv, Ukraine, 03680 \\ ${ }^{2}$ Educational and Scientific Center "Institute of Biology", \\ Taras Shevchenko National University of Kyiv \\ 64/13, Volodymyrska Str., Kyiv, Ukraine, 01601 \\ livshits@imbg.org.ua
}

\begin{abstract}
Aim. To evaluate a possible role of a novel c.A212G substitution in the PUS3 gene at intellectual disability (ID). Methods. The observed group consisted of the ID Ukrainian family members (parents and two affected children) and the control group - of 300 healthy individuals from general population of Ukraine. Sanger sequencing of the PUS3 gene exon 1 was performed for the family members. Polymorphic variants of c.A212G were analyzed using ARMS PCR. The homology models of wild type and p.Y71C mutant catalytic domains of human Pus3 were generated using the crystal structure of the human Pus1 catalytic domain (PDB ID: 4NZ6) as a template. Results. It was shown that the father of the affected siblings was the c.A212G substitution heterozygous carrier whereas the mother was a wild type allele homozygote, and the exom sequencing result was confirmed - the affected children are $212 \mathrm{G}$ homozygotes. We supposed de novo mutation in the maternal germ line. A low frequency of $212 \mathrm{G}$ allele $(0.0017)$ was shown in the population of Ukraine. Homology modelling of the wild type and p.Y71C mutant catalytic domain of human Pus3 revealed that substitution p.Y71C is located in close proximity to its active site. Conclusions. The absence of hypoproteinemia in our patients, homozygous for the $212 \mathrm{C}$ allele allows us to assume that the mutation c.A212G PUS3 is rather neutral and cannot be the major cause of ID. However, considering a low frequency of the $212 \mathrm{G}$ allele in the population and close localization of p.Y71C substitution to the active site of hPus3 we cannot exclude that the c.A212G mutation in PUS3 may be a modifier for some pathologies including syndromic ID.
\end{abstract}

Key w or d s: PUS3 gene, intellectual disability, mutation, population, pseudouridine.

\section{Introduction}

In the frame of CHERISH project (no. 223692) devoted to the genetic basis of intellectual disability, the next generation exome sequencing was conducted for two affected children (proband and his younger sibling) from the Ukrainian family (UKR 094) with healthy non-consanguineous parents. The proband (UKR 263) is a 12-year-old boy with non-syndromic ID (IQ 43), hypermobility of joints, hyperactivity and mild dysmorphic features. His brother (UKR 264 ) is a 4-year-old boy with non-syndromic ID, epilepsy, hypermobility of joints and mild dysmorphic features. The biochemical analysis of blood revealed no deviations from the normal ranges for the main groups of blood plasma proteins, aminoacids and acylcarnitines examined by TANDEM MS in both probands. The previous extensive genetic investigations (karyotype analysis and array-CGH analysis (400K resolution) have not found out any abnormalities as well.

The exome analysis revealed several variants in either homozygous or compound heterozygous state in few genes: EPHA1 [1], PUS3 and ZNF527.

\footnotetext{
(C) 2015 R. V. Gulkovskyi et al.; Published by the Institute of Molecular Biology and Genetics, NAS of Ukraine on behalf of Biopolymers and Cell. This is an Open Access article distributed under the terms of the Creative Commons Attribution License (http://creativecommons.org/licenses/by/4.0/), which permits unrestricted reuse, distribution, and reproduction in any medium, provided the original work is properly cited
} 
Among these candidates, we decided to concentrate on the PUS3 gene, where novel homozygous SNP c.A212G (NM_031307:c.A212G:p.Y71C) was detected in both ID-patients. The PUS3 gene is located at chromosome 11q24.2 and conserved from Escherichia coli to human [2].

The human pseudouridine synthase 3 (hPus3) is a member of the tRNA pseudouridine synthase truA family and involved in the formation of pseudouridine $(\Psi)$ at position 39 in the anticodon stem and loop (ASL) of many transfer RNAs [3, 4]. $\Psi$ is found in almost all tRNAs, $\Psi$ 's at positions $38-40$ in the Anticodon Stem Loop of tRNAs play an important role in maintaining translational efficiency and accuracy [5]. Pseudouridine appears to be necessary for the correct codon-anticodon interactions $[6,7]$ and to prevent mischarging of the tRNA [8]. It was shown that the mouse Pus3 (mPus3) can also serve as a nuclear receptors (NR) coactivator (as well as mPus1 known to form pseudouridine at positions 27, 28, 34, and 36 in tRNAs), except that it does not enhance the sex steroid receptor activity [4]. A mutation in the PUS1 gene (another truA family member) has been linked to the mitochondrial myopathy and sideroblastic anemia [4, 9-11].

To evaluate a possible involvement of the PUS3 gene c.A212G mutation in intellectual disability, as the first step, we analyzed this mutation in the healthy parents of the affected children and in general population of Ukraine and modeled 3D structure of the hPus3 catalytic domain to define if the change in p.Y71C position influences the 3D structure of human Pus3 protein.

\section{Materials and Methods}

The observed group consisted of 300 adult (25-30 years-old) individuals including 164 (54.6\%) males and $136(45.3 \%)$ females. This group is representative for the estimation of DNA polymorphism frequency in autosomal genes [12, 13].

The DNA-samples were extracted from peripheral blood leucocytes of unrelated volunteer donors from different regions of Ukraine by the standard phenolchloroform method. Informed consents were obtained from all the individuals participating in our study.

The polymorphic variants c.A212G found through exome sequencing in the affected children (from UKR 094 family) were analyzed in the DNA samples of their parents by Sanger sequencing. This analysis was performed by the standard dideoxynucleotide chain-termination method using $\left[{ }^{35} \mathrm{~S}\right]-\mathrm{dATP}$ or $\left[{ }^{35} \mathrm{~S}\right]-\mathrm{dCTP}(\mathrm{ICN})$, the Sequenase version 2.0 DNA sequencing kit (USB), «ABI Prism Big Dye Terminator Cycle Sequincing Ready Reaction Kits» and ABI Prism 3110 Genetic Analyser (Applied Biosystems Analysis of the c.A212G substitution was performed by ARMS (amplification refractory mutation system). The primers were designed using the web-based PRIMER 3.0 program (http://workbench.sdsc.edu) and the «BLAST» (http://www.ncbi.nlm.nih.gov/ blast) (Table 1).

Amplification of the allele $212 \mathrm{~A}$ is accomplished using a complementary primer «wild type» paired with a «forward» primer (Table 1). On the other hand, the $212 \mathrm{G}$ allele will be amplified if the 3 ' residue of primer is complementary to the «mutant» se-

Table 1. Sequences of ARMS-PCR primers used in genotping reactions

\begin{tabular}{|l|l|c|}
\hline Substitution & Nucleotide sequence & Amplicon size, bp \\
\hline \multirow{2}{*}{ c.A212G } & CTGGAGCAAGAGGTGCAAAGACT - «forward» & 320 \\
& ACCTGTCCAAAGGCACTAACTCC - «reverse» & 193 \\
C.A212G & GACACGTAGCCCTAAGAATAGCCTa - «wild type» & 172 \\
& CCTGGTATCCCCAGCCCATAc - «mutant» & \\
\hline
\end{tabular}


quence - PCR product flanked by «mutant» and «reverse» primers (Table 1). Thus, as a result a normal individual generates PCR product (193 bp) only in the normal reaction; a heterozygote gives products (193 bp and 172 bp) in both reactions, and a homozygous mutant individual gives amplification (172 bp PCR product) only in the case of mutant variant. The PCR product flanked by «forward» and «reverse» primers (320 bp) will be amplified in all reactions (Fig.1).

Thereby three different patterns could be observed for the c.A212G variant after the amplification: 320 bp and 193 bands (for A/A); 320 bp, 193 bp and 172 bp bands (for $\mathrm{A} / \mathrm{G}$ ); $320 \mathrm{bp}$ and 172 bp bands (for G/ G) (Fig. 3).

The PCR amplification was performed in one tube in a final volume of $25 \mu$ containing $1 \times$ PCR buffer, 1.5 $\mathrm{mM} \mathrm{MgCl}, 200 \mu \mathrm{M}$ of each dNTP, $1 \mu \mathrm{M}$ of each primer, 0.2 units of Taq-DNA polymerase and $200 \mathrm{ng}$ of the DNA template. The cycling conditions were as follows: initial denaturation at $94{ }^{\circ} \mathrm{C}$ for $5 \mathrm{~min}, 30$ cycles consisting of denaturation at $94{ }^{\circ} \mathrm{C}$ for $30 \mathrm{~s}$, annealing at 64 ${ }^{\circ} \mathrm{C}$ for 30 s, extension at $72{ }^{\circ} \mathrm{C}$ for 30 s, and a final elongation step at $72^{\circ} \mathrm{C}$ for $3 \mathrm{~min}$. The amplified fragments were analyzed by electrophoresis in $2 \%$ agarose gel. The sample that previously underwent Sanger sequencing was used as a positive control.

Multiple sequence alignment was performed according to the Homologene program with default settings and the sequences: NP_079491.2 (Homo sapiens), NP_112597.3 (Homo sapiens), XP_001148378.1 (Pan troglodytes), XP_001111887.1 (Macaca mulatta), NP_075781.3 (Mus musculus), NP_001101604.1 (Rattus norvegicus), XP 536533.1 (Canis lupus familiaris), NP 001029684.1(Bostaurus), XP_004948004.1 (Gallus gallus), NP_956361.1 (Danio rerio), NP_9 88969.1 (Xenopus tropicalis), NP_611646.1 (Drosophila melanogaster), XP_318500.4 (Anopheles gambiae str.), NP_496062.3 (Caenorhabditis elegans), NP_116655.1 ('Saccharomyces cerevisiae), XP_454596.1 (Kluyveromyces lactis) and P07649.1 (Escherichia coli). The sequences of the Homo sapiens hPus3 and hPus1 proteins and homologous proteins from other species were obtained from the NCBI database (http://www.ncbi.nlm.nih.gov/).

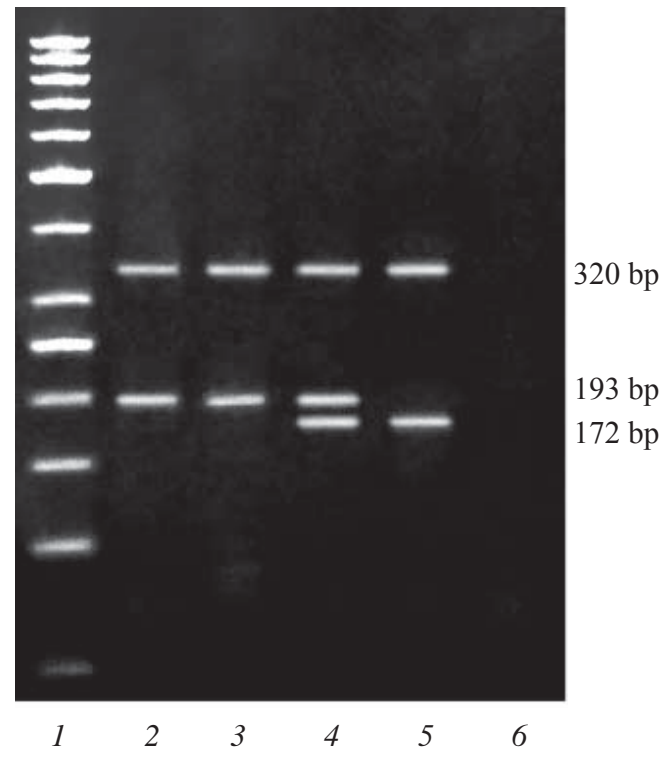

Fig. 1. Electrophoregram for the ARMS analysis of c.A212G PUS3 gene variants ( $2 \%$ agarose gel electrophoresis): 1 - molecular weight marker (50 bp ladder); 2, 3 - individuals with homozygous genotype AA; 4 - individual with heterozygous genotype AG; 5 - individual with homozygous genotype GG and $6-$ negative control

In silico modeling. The homology models of wild type and mutant (p.Y71C) catalytic domains of human Pus3 were generated by Swiss Model server (http://swissmodel.expasy.org) using as a template a crystal structure of the human (mitochondrial) Pus1 catalytic domain (PDB ID: 4NZ6).

\section{Results and Discussion}

The Sanger sequencing of the gene PUS3 exon 1 revealed that probands UKR 263 and UKR 264 are homozygotes for the c.A212G substitution that confirms the exome sequencing results. In turn, the father (UKR 266) of the affected siblings is a heterozygous carrier for the c.A212G substitution and, surprisingly, the mother (UKR 265) is a wild type allele homozygote (Fig. 2).

The possible explanation of such results is the de novo mutation in the maternal germ line.

Of the 300 analyzed samples, we found one heterozygous carrier for the c.A212G mutation only. Thus, the genotypes distribution was as follows: A/A $99.7 \%, \mathrm{~A} / \mathrm{G}-0.3 \%$ and $\mathrm{GG}-0 \%$. The observed 

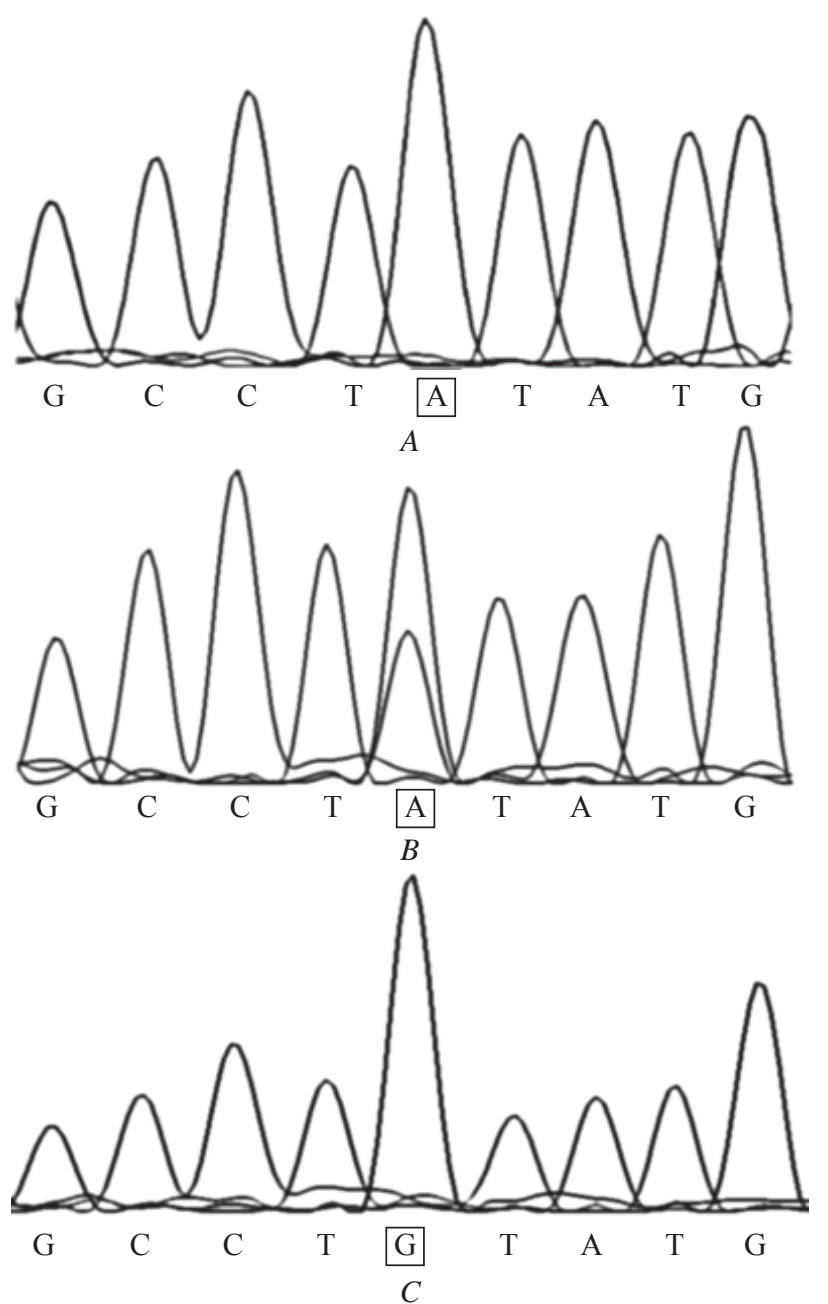

Fig. 2. Representative sequence chromatogram of the PUS3 gene loci with c.A212G substitution PCR products: $A$ - UKR 265 (mother) - wild type allele homozygote (AA); B - UKR 266 (father) - heterozygous carriers of the c.A212G substitution; $C$ UKR 263 and UKR 264 - homozygous GG

genotype distribution showed no deviations from Hardy-Weinberg expectations. The PUS3 212G (mutant) allele frequency was 0.0017 and $212 \mathrm{~A}$ (wild type) -0.9983 . To our knowledge, this is the first published data on the c.A212G PUS3 gene variants distribution in the populations.

Pseudouridylate synthase 3 is a 481 amino acid (aa) protein that belongs to the highly conserved tRNA pseudouridine synthase truA family and mostly is localized to cytoplasm and nucleus $[3,4,14]$. The members of this family have been shown to modify multiple positions in cytoplasmic and mitochondrial tRNAs
$[11,15]$, as well as non-tRNA substrates: U2 snRNA [16] and SRA [17]. The TruA family includes Pus1 from E. coli (also called truA or hisT) which modifies positions 38,39 , and 40 in the ASL of bacterial tRNAs [18]. Other members are Pus3 from mouse [1]; Pus3 from yeast (also known as Deg1) - modifies positions 38 and 39 [14] and human mitochondrial Pus1 modifies positions 27, 28, 34, and 36 in tRNAs in vitro and in vivo $[19,20]$. The atomic models for various members of the PUS families (TruA, TruB, TruD, RluA, RsuA, and Pus10) have been solved and have shown a conserved catalytic core that presents a high degree of structural similarity and is the most stable region of the protein. [21-28].

The c.A212G mutation results in substitution of aromatic Tyrosine 71 to sulfur-containing Cysteine located in the catalytic domain of human Pus3. The analyses of site orthologs, using the NCBI HomoloGene database, revealed that the Tyr71 amino acid position is conserved from Escherichia coli to human, indicating that there may be an evolutionarily conserved function (Fig. 3).

To define if the change in $\mathrm{p} . Y 71 \mathrm{C}$ position influences the 3D structure of human Pus3 protein, we modeled the hPus 3 catalytic domain 3D structure using the crystal structures of the human (mitochondrial) Pus1 catalytic domain as a template (Fig. 4, C and D). The mitochondrial hPus1, as well as hPus3, belongs to the tRNA pseudouridine synthase TruA family and is mostly localized in the mitochondria $[16,17,29]$.

From the crystal structure of the bacterial TruA (Fig. 4, A) it is known that the active site of the TruA family members is populated by four strictly conserved amino acids including a catalytic aspartate (D60 in TruA), two arginines (R58 and R205), and a tyrosine (Y118) [22]. These residues correspond to D146, R144, R295, Y201 in hPus1 (Fig. 4, B) and D118, R116, R280 and Y195 in hPus3 (see Fig. 4, C and $4, D)[22,27,28,30]$. Tyrosine 71 of hPus3, corresponding to Y18 in bacterial TruA and Y92 - in hPus1, is another strictly conserved amino acid (Fig. 3). As can be seen from Fig. 4, $C$ and 4, D, the substitution of highly conserved aromatic Tyrosine 71 to sulfur-containing Cysteine is located in close proximity to the active site of hPus3 and may directly cause 
Novel gene PUS3 c.A212G mutation in Ukrainian family with intellectual disability

the changes in catalytic domain conformational flexibility and spatial organization. Nevertheless, we still cannot suppose that the p.Y71C mutation may result in the change of pseudouridylate synthase efficiency of hPus3, Tyr71 (shown in black boxes) from Escherichia coli to human. Tyrosine 71 of hPus3 corresponds to Y92 in hPus1 (shown in black boxes).

This is true considering the fact that Sibert et al., interpreting the site-directed mutagenesis experiments with hPus1, indicate that Y173 (corresponds to Y195 in hPus3), and R267 (corresponds to R280 in hPus3) known to compose the active site of TruA of the enzyme near a critical aspartate (position 118), do not play any essential role in the catalysis [30]. They changed Tyr201 and Arg295 to several other amino acids and found that many variants had significant activity [30].

However, $\Psi$ 's at positions $38-40$ in the Anticodon Stem Loop of tRNAs plays an important role in maintaining translational efficiency and accuracy. These modifications of uridines were shown to increase the thermal stability of the ASL, which could affect the anticodon-codon interaction or conformational changes of the tRNA during translation and spliceosome assembly $[5,32]$. Thus, the PUS3 mutations, that result in loss of pseudouridine in a wide range of tRNAs, may affect the protein synthesis.

The strong relationship between the reduced growth rate of $E$. coli or $S$. typhimurium and the absence of pseudouridines 38-40 in anticodon stemloop of several tRNAs was reported more than two decades ago [33]. The HisT mutant E. coli strains display a $20-25 \%$ reduction in the rate of polypeptide chain elongation and exhibit pleiotropic abnormalities in the cell division processes, resulting in an increase in doubling time of more than $30 \%$ [34]. When the PUS3 gene was disrupted in yeast, it was not lethal, but the growth rate of the yeast considerably reduced, especially at $37^{\circ} \mathrm{C}$ [14]. Since there is an effect on the growth of prokaryotes and yeast when the pseudouridine 38-40 synthase activity is deleted, what might be the effect of the PUS3 gene missense mutations in humans?

The physiological importance of the appropriate pseudouridine synthase activity is illustrated by the

\begin{tabular}{|c|c|}
\hline Mutated & AFDFSAHGRRHVALRIACMGWGYQGFASQE \\
\hline H. sapiens & AFDF SAHGRRHVALRIACMGWGYQGFASQE \\
\hline P. troglodytes & AFDFSAHGRRHVALRIAYMGWGYQGFASQE \\
\hline M. mulatta & AFDFSAHGRRHVALRIAYMGWGYQGFASQE \\
\hline M. musculus & AFDFSAHGRRHVALKIAYLGWGYQGFASQE \\
\hline$R$. norvegicus & AFDFSAHGRRHVALKIAYLGWGYQGFASQE \\
\hline C. lupus familiaris & AFDFSAHGRRHVALKIAYLGWGYQGFASQE \\
\hline B. taurus & AFDFSAHGQRHVALKIAYLGWGYQGFASQE \\
\hline G. gallus & PFDFSAHGRRHVALRIAYLGWGYQGFASQE \\
\hline D. rerio & PFDFSAHPRRHVALRLAYLGWQYQGFAVQE \\
\hline X. tropicalis & AFDF SAHP KQHVALRLAYLGWGYQGFASQE \\
\hline D. melanogaster & KFDWSSAHKRHVLLKITYLGWDYQGFACQE \\
\hline A. gambiae str. & PFDFAKCFKRH I LLRFYYLGWGYQGFAAQE \\
\hline C. elegans & TLDF LAHPRRKIAIQFFYLGWEHDGLVQQP \\
\hline S. cerevisiae & KFDFSKHNTRF IALRFAYLGWNYNGLAVQK \\
\hline K. lactis & EFDFSKYNTRFVAFKFAYLGWNYNGLAIQK \\
\hline E. coli & MSDQQQPPVYKIALGIEYDGSKYYGWQRQN \\
\hline H. sapiens & AFDFSAHGRRHVALRIAYMGWGYQGFASQE \\
\hline H sapiens $P U S 1$ & -------SKRKIVLLMAYSGKGYHGMQRNV \\
\hline
\end{tabular}

Fig. 3. Pseudouridylate synthase 3 (481 aa) conservation analysis. Conserved amino acid positions are shown in grey boxes. Protein alignment showed conservation of residue Tyr71 (shown in black boxes) from Escherichia coli to human. Tyrosine 71 of hPus 3 corresponds to Y92 in hPus1 (shown in black boxes)

disorders such as DKC (dyskeratosis congenital) and MLASA (mitochondrial myopathy and sideroblastic anemia) [9-11, 35]. A missense mutation in the human PUS1 gene affecting a highly conserved amino acid (Arg144-to-Trp mutation in the active site of the enzyme and a mutation of Glu220, which leads to C-terminally truncated protein) has been associated with mitochondrial myopathy and sideroblastic anemia, a rare autosomal recessive disorder of oxidative phosphorylation and iron metabolism [9-11]. The X-linked form of the only other known human disease of pseudouridylation dyskeratosis congenita is caused by the mutations in the gene encoding dyskerin [35].

The previously mentioned PUS1 mutations result in the loss of pseudouridine in some tRNAs that may affect protein synthesis [9-11]. Furthermore, the mammalian pseudouridine synthase 1 (Pus1) was reported to modulate the class I and class II nuclear receptor responses through its ability to modify the Steroid receptor RNA Activator (SRA) [4, 17, 28] and it was suggested that other abnormalities in these MLASA patients, such as facial dysmorphisms, may be due to 

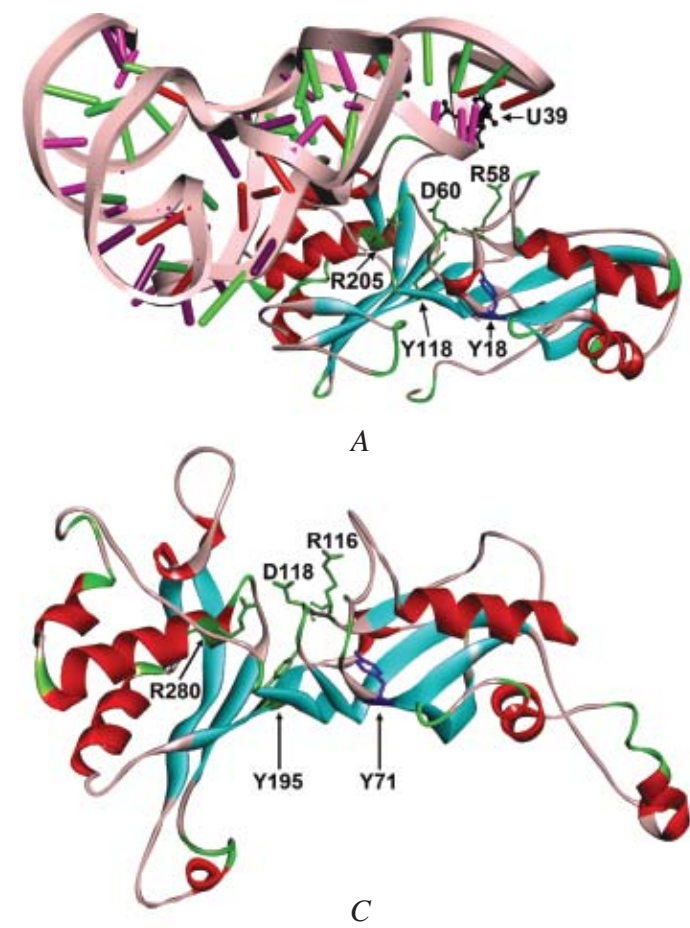

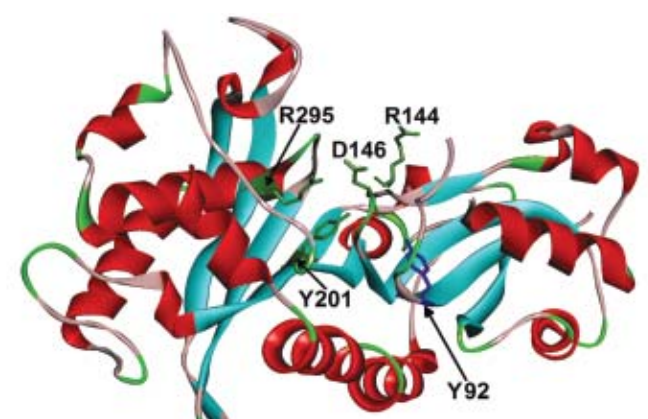

$B$

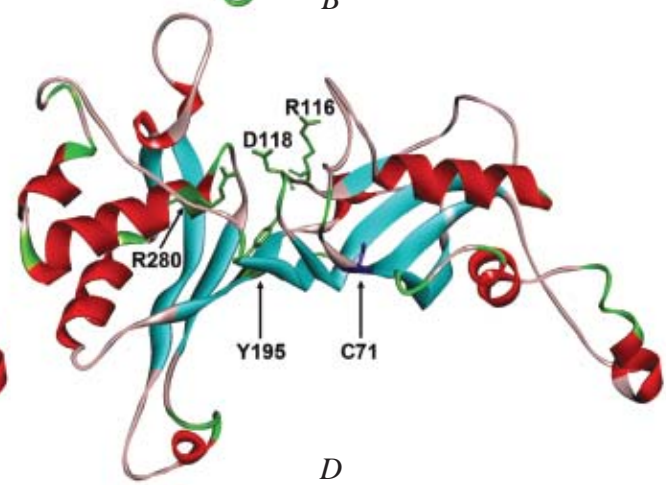

Fig. 4. Overall views of the crystal structure of bacterial TruA (PDB ID: 2NQP) (A), hPus1 (PDB ID: 4NZ6) (B) and homology models of wild type $(C)$ and p.Y71C mutant $(D)$ hPus3 catalytic domain. Crystal structure of pseudoudirinde synthase TruA monomer in complex with leucyl tRNA $(A)$ - uracil 39 shown in ball and stick model and colored in black, the catalytic amino acid residues D146, R144, R295 and Y201 are shown as sticks and colored in green, Y92 shown in stick model and colored in blue. The hPus1 monomer $(B)$ - catalytic amino acid residues D60, R58, R205 and Y118 are shown as sticks and colored in green, Y18 shown in stick model and colored in blue. Homology models of wild-type $(C)$ and p.Y71C mutant $(D)$ catalytic domain of human Pus 3 generated by Swiss Model server. The images were created by ViewerLite v.4.2 with Y71 mutation sites shown in blue, residues D118, R116, R280 and Y195 are shown in green [28, 31]

the loss of this activity of Pus1 [10]. Recently it has been shown that Pus3 (as well as Pus1) acts as a regulator of the nuclear receptors activity [4]. Therefore, it cannot be excluded that some symptoms observed in the affected children from Ukrainian family (UKR 094), such as facial dysmorphisms, may be the consequence of defective hSRA-NR signaling.

However, in some known human pseudouridylation diseases, the loss of pseudouridine that results in a decrease of the protein synthesis efficiency, has a pleiotropic effect which causes syndromic pathologies. The similar pleiotropic effect may take place in case of the c.A212G mutation in the PUS3 gene indentified in this study. Nevertheless, we did not observe syndromic intellectual disability in the affected children from Ukrainian family (UKR 094). Furthermore, in our patients we did not detect any evi- dence of hypoproteinemia, which is a common indicator for both MLASA and DKC and may be an evidence of the deficiency in protein synthesis.

Thus, we assume that the c.A212G PUS3 mutation is rather neutral and cannot be the major cause of intellectual disability. However, considering a low frequency of the $212 \mathrm{G}$ allele $(0.0017)$ in the population of Ukraine and the location of p.Y71C substitution in close proximity to the active site of hPus3 protein we cannot exclude that the c.A212G mutation in the PUS3 gene may still be considered as a modifying factor for some pathologies including syndromic intellectual disability.

Further studies will be carried out to evaluate the influence of the c.A212G PUS3 gene mutation on the pseudouridylate synthase efficiency and its involvement in the ID development. 
Novel gene PUS3 c.A212G mutation in Ukrainian family with intellectual disability

\section{Acknowledgements}

We thank the family for its cooperation. We thank M. Noukas, M. Sauk, L. Milani, T. Pippucci, F. Balombo for their kind assistance in the next generation exome sequencing of the UKR 094 family members.

\section{REFERENCES}

1. Gulkovskyi RV, Chernushyn SY, Kravchenko SA, Bychkova GM, Livshits LA. EPHA1 gene SNPs analysis in population of Ukraine. Biopolym Cell. 2013;29(6):506-10.

2. Satoh J, Kawana N, Yamamoto Y. Pathway analysis of ChIPSeq-Based NRF1 target genes suggests a logical hypothesis of their involvement in the pathogenesis of neurodegenerative diseases. Gene Regul Syst Bio. 2013;7:139-52.

3. Chen J, Patton JR. Pseudouridine synthase 3 from mouse modifies the anticodon loop of tRNA. Biochemistry. 2000; 39(41):12723-30.

4. Zhao X, Patton JR, Ghosh SK, Fischel-Ghodsian N, Shen L, Spanjaard RA. Pus3p- and Pus1p-dependent pseudouridylation of steroid receptor RNA activator controls a functional switch that regulates nuclear receptor signaling. Mol Endocrinol. 2007;21(3):686-99.

5. Agris PF. Decoding the genome: a modified view. Nucleic Acids Res. 2004;32(1):223-38.

6. Tomita K, Ueda T, Watanabe K. The presence of pseudouridine in the anticodon alters the genetic code: a possible mechanism for assignment of the AAA lysine codon as asparagine in echinoderm mitochondria. Nucleic Acids Res. 1999; 27(7):1683-9.

7. Zerfass K, Beier H. Pseudouridine in the anticodon G psi A of plant cytoplasmic tRNA(Tyr) is required for UAG and UAA suppression in the TMV-specific context. Nucleic Acids Res. 1992;20(22):5911-8.

8. Perret V, Garcia A, Grosjean H, Ebel JP, Florentz C, Giegé $R$. Relaxation of a transfer RNA specificity by removal of modified nucleotides. Nature. 1990;344(6268):787-9.

9. Bykhovskaya Y, Casas K, Mengesha E, Inbal A, Fischel-Ghodsian N. Missense mutation in pseudouridine synthase 1 (PUS1) causes mitochondrial myopathy and sideroblastic anemia (MLASA). Am J Hum Genet. 2004;74(6):1303-8.

10. Fernandez-Vizarra E, Berardinelli A, Valente L, Tiranti V, Zeviani $M$. Nonsense mutation in pseudouridylate synthase 1 (PUS1) in two brothers affected by myopathy, lactic acidosis and sideroblastic anaemia (MLASA). J Med Genet. 2007;44(3):173-80.

11. Patton JR, Bykhovskaya Y, Mengesha E, Bertolotto C, Fischel-Ghodsian N. Mitochondrial myopathy and sideroblastic anemia (MLASA): missense mutation in the pseudouridine synthase 1 (PUS1) gene is associated with the loss of tRNA pseudouridylation. J Biol Chem. 2005;280(20):19823-8.

12. Cordell HJ, Clayton DG. Genetic association studies. Lancet. 2005;366(9491):1121-31.
13. Balding DJ. A tutorial on statistical methods for population association studies. Nat Rev Genet. 2006;7(10):781-91.

14. Lecointe F, Simos G, Sauer A, Hurt EC, Motorin Y, Grosjean H. Characterization of yeast protein Deg1 as pseudouridine synthase (Pus3) catalyzing the formation of psi 38 and psi 39 in tRNA anticodon loop. J Biol Chem. 1998;273(3):1316-23.

15. Chen J, Patton JR. Mouse pseudouridine synthase 1: gene structure and alternative splicing of pre-mRNA. Biochem J. 2000;352 Pt 2:465-73.

16. Behm-Ansmant I, Massenet S, Immel F, Patton JR, Motorin Y, Branlant $C$. A previously unidentified activity of yeast and mouse RNA:pseudouridine synthases 1 (Pus1p) on tRNAs. RNA. 2006;12(8):1583-93.

17. Zhao X, Patton JR, Davis SL, Florence B, Ames SJ, Spanjaard $R A$. Regulation of nuclear receptor activity by a pseudouridine synthase through posttranscriptional modification of steroid receptor RNA activator. Mol Cell. 2004;15(4):549-58.

18. Kammen HO, Marvel CC, Hardy L, Penhoet EE. Purification, structure, and properties of Escherichia coli tRNA pseudouridine synthase I. J Biol Chem. 1988;263(5):2255-63.

19. Chen J, Patton JR. Cloning and characterization of a mammalian pseudouridine synthase. RNA. 1999;5(3):409-19.

20. Motorin $Y$, Keith G, Simon C, Foiret D, Simos G, Hurt E, Grosjean $H$. The yeast tRNA:pseudouridine synthase Pus1p displays a multisite substrate specificity. RNA. 1998;4(7): 856-69.

21. McCleverty CJ, Hornsby M, Spraggon G, Kreusch A. Crystal structure of human Pus10, a novel pseudouridine synthase. J Mol Biol. 2007;373(5):1243-54.

22. Foster PG, Huang L, Santi DV, Stroud RM. The structural basis for tRNA recognition and pseudouridine formation by pseudouridine synthase I. Nat Struct Biol. 2000;7(1):23-7.

23. Sivaraman J, Sauvé V, Larocque R, Stura EA, Schrag JD, Cygler M, Matte A. Structure of the 16S rRNA pseudouridine synthase RsuA bound to uracil and UMP. Nat Struct Biol. 2002;9(5):353-8.

24. Ericsson UB, Nordlund P, Hallberg BM. X-ray structure of tRNA pseudouridine synthase TruD reveals an inserted domain with a novel fold. FEBS Lett. 2004;565(1-3):59-64.

25. Mizutani K, Machida Y, Unzai S, Park SY, Tame JR. Crystal structures of the catalytic domains of pseudouridine synthases RluC and RluD from Escherichia coli. Biochemistry. 2004;43(15):4454-63.

26. Koonin EV. Pseudouridine synthases: four families of enzymes containing a putative uridine-binding motif also conserved in dUTPases and dCTP deaminases. Nucleic Acids Res. 1996;24(12):2411-5.

27. Czudnochowski N, Wang AL, Finer-Moore J, Stroud RM. In human pseudouridine synthase 1 (hPus1), a C-terminal helical insert blocks tRNA from binding in the same orientation as in the Pus1 bacterial homologue TruA, consistent with their different target selectivities. J Mol Biol. 2013;425(20): 3875-87.

28. Huet T, Miannay FA, Patton JR, Thore S. Steroid receptor RNA activator (SRA) modification by the human pseudou- 
ridine synthase 1 (hPus1p): RNA binding, activity, and atomic model. PLoS One. 2014;9(4):e94610.

29. Simos G, Tekotte H, Grosjean H, Segref A, Sharma K, Tollervey $D$, Hurt EC. Nuclear pore proteins are involved in the biogenesis of functional tRNA. EMBO J. 1996;15(9):2270-84.

30. Sibert BS, Fischel-Ghodsian N, Patton JR. Partial activity is seen with many substitutions of highly conserved active site residues in human Pseudouridine synthase 1. RNA. 2008;14 (9):1895-906.

31. Hur S, Stroud RM. How U38, 39, and 40 of many tRNAs become the targets for pseudouridylation by TruA. Mol Cell. 2007;26(2):189-203.

32. Yu YT, Shu MD, Steitz JA. Modifications of U2 snRNA are required for snRNP assembly and pre-mRNA splicing. $E M B O$ J. 1998;17(19):5783-95.

33. Winkler ME. Biosynthesis of histidine. In Escherichia coli and Salmonella Cellular and Molecular Biology. 1, 2nd ed. (Neidhardt FC, ed.). Washington DC: ASM Press, 1996; pp. 485-505.

34. Tsui HC, Arps PJ, Connolly DM, Winkler ME. Absence of hisT-mediated tRNA pseudouridylation results in a uracil requirement that interferes with Escherichia coli K-12 cell division. J Bacteriol. 1991;173(22):7395-400.

35. Mitchell JR, Wood E, Collins K. A telomerase component is defective in the human disease dyskeratosis congenita. $\mathrm{Na}$ ture. 1999;402(6761):551-5.

\section{Нова мутація с.A212G гена PUS3 в українській родині 3 інтелектуальною недісздатністю}

Р. В. Гулковський, С. Ю. Чернушин, Л. А. Лівшиць

Мета. Оцінити можливу роль нової заміни с.A212G в гені PUS3 в розвитку інтелектуальній недієздатності (IH). Методи. Група спостереження складалася 3 членів української родини з ІН (батьків і двох хворих дітей) та контрольної групи з 300 здорових осіб із загальної популяції України. Для членів родини проводили секвенування по Сангеру екзона 1 гена PUS3. Поліморфні варіанти с.А212G аналізували з використанням ARMS ПЛР. Моделі дикого типу і мутантного p.Y71C каталітичних доменів Pus3 людини були побудовані за гомологією, з використанням кристалічної структури каталітичного домену Pus1 людини (PDB ID: 4NZ6) як матрицю. Результати. Показано, що батько хворих сиблінгів $\epsilon$ гетерозиготним носієм заміни с.A212G, а мати - гомозиготною за алелем дикого типу, і підтверджено результат екзомного секвенування, що обидва хворих сиблінга є гомозиготами $212 \mathrm{G}$. Ми припускаємо de novo мутацію в оогенезі матері. Була показана низька частота $212 \mathrm{G}$ алеля $(0,0017)$ в популяції України. Моделювання по гомології дикого типу та мутантного p.Y71C каталітичного домену Pus3 людини показало, що заміна p.Y71C розташована в безпосередній близькості від іiї активного центру. Висновки. Відсутність гіпопротеїнемії у наших пацієнтів, гомозиготних за 212C алелем, дозволяє припустити, що мутація с.A212G в PUS3 ймовірно нейтральна i не може бути основною причиною $\mathrm{IH}$. Але, враховуючи низьку частоту $212 \mathrm{G}$ алеля в популяції i близьку локалізацію заміни р.Y71C до активного сайту hPus3, ми не можемо виключити, що мутація с.A212G в PUS3 може бути модифікуючим фактором для деяких патологій, включаючи синдромальну IH.

К л ю ч о в і с л о в а: ген PUS3, інтелектуальнанедієздатність, мутація, популяція, псевдоуридин.

\section{Новая мутация с.A212G гена PUS3 в украинской семье с интеллектуальной недееспособностью}

\section{Р. В. Гулковский, С. Ю. Чернушин, Л. А. Лившиц}

Цель. Оценить возможную роль новой замены с.A212G в гене PUS3 в развитии интеллектуальной недееспособности (ИН). Методы. Группа наблюдения состояла из членов украинской семьи с ИН (родителей и двух больных детей) и контрольной группы 300 здоровых человек из общей популяции Украины. Для членов семьи проводили секвенирование по Сангеру экзона 1 гена PUS3. Полиморфные варианты с.A212G анализировали с использованием ARMS ПЦР. Модели дикого типа и мутантного p.Y71C каталитических доменов Pus3 человека были построены по гомологии, с использованием кристаллической структуры каталитического домена Pus1 человека (PDB ID: 4NZ6) в качестве матрицы. Результаты. Показано, что отец больных сиблингов является гетерозиготным носителем замены с.A212G, а мать - гомозиготной по аллелю дикого типа, и подтверждено результат экзомного секвенирование, что оба больных сиблинга являются гомозиготами $212 \mathrm{G}$. Мы предполагаем de novo мутацию в оогенезе матери. Была показана низкая частота $212 \mathrm{G}$ аллеля $(0,0017)$ в популяции Украины. Моделирование по гомологии дикого типа и мутантного p.Y71C каталитических доменов Pus3 человека показало, что замена $\mathrm{p} . Y 71 \mathrm{C}$ расположена в непосредственной близости от его активного центра. Выводы. Отсутствие гипопротеинемии у наших пациентов, гомозиготных по 212C аллелю, позволяет предположить, что мутация с.A212G в PUS3 вероятно нейтральна и не может быть основной причиной ИН. Но, учитывая низкую частоту $212 \mathrm{G}$ аллеля в популяции и близкую локализацию замены p.Y71C к активному сайту hPus3, мы не можем исключить, что мутация с.A212G в PUS3 может быть модифицирующим фактором для некоторых патологий, включая синдромальную ИН.

Кл юч в в е с лов а: ген PUS3, интеллектуальная недееспособность, мутация, популяция, псевдоуридин.

Received 3.02.2015 